BMJ Open

Diabetes

Research

\& Care
To cite: Hodik M, Skog 0, Lukinius A, et al. Enterovirus infection of human islets of Langerhans affects $\beta$-cell function resulting in disintegrated islets, decreased glucose stimulated insulin secretion and loss of Golgi structure. BMJ Open Diabetes Research and Care 2016;4:e000179.

doi:10.1136/bmjdrc-2015000179

$\mathrm{MH}$ and $\mathrm{OS}$ contributed equally to the work.

Received 7 December 2015 Revised 27 April 2016 Accepted 2 May 2016

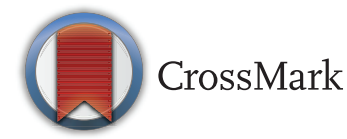

${ }^{1}$ Department of Immunology, Genetics and Pathology, The Rudbeck Laboratory, Uppsala University, Uppsala, Sweden 2Department of Cell Biology, University Medical Center Groningen, University Groningen, Groningen, The Netherlands

Correspondence to Dr G Frisk;

gun.ergida.frisk@gmail.com

\title{
Enterovirus infection of human islets of Langerhans affects $\beta$-cell function resulting in disintegrated islets, decreased glucose stimulated insulin secretion and loss of Golgi structure
}

\author{
M Hodik, ${ }^{1}$ O Skog, ${ }^{1}$ A Lukinius, ${ }^{1}$ J M Isaza-Correa, ${ }^{2}$ J Kuipers, ${ }^{2}$ B N G Giepmans, ${ }^{2}$ \\ G Frisk $^{1}$
}

\section{ABSTRACT}

Aims/hypothesis: In type 1 diabetes (T1D), most insulin-producing $\beta$ cells are destroyed, but the trigger is unknown. One of the possible triggers is a virus infection and the aim of this study was to test if enterovirus infection affects glucose stimulated insulin secretion and the effect of virus replication on cellular macromolecules and organelles involved in insulin secretion.

Methods: Isolated human islets were infected with different strains of coxsackievirus B (CVB) virus and the glucose-stimulated insulin release (GSIS) was measured in a dynamic perifusion system. Classical morphological electron microscopy, large-scale electron microscopy, so-called nanotomy, and immunohistochemistry were used to study to what extent virus-infected $\beta$ cells contained insulin, and realtime PCR was used to analyze virus induced changes of islet specific genes.

Results: In islets infected with CVB, GSIS was reduced in correlation with the degree of virus-induced islet disintegration. The expression of the gene encoding insulin was decreased in infected islets, whereas the expression of glucagon was not affected. Also, in islets that were somewhat disintegrated, there were uninfected $\beta$ cells. Ultrastructural analysis revealed that virus particles and virus replication complexes were only present in $\beta$ cells. There was a significant number of insulin granules remaining in the virus-infected $\beta$ cells, despite decreased expression of insulin mRNA. In addition, no typical Golgi apparatus was detected in these cells. Exposure of islets to synthetic dsRNA potentiated glucose-stimulated insulin secretion.

Conclusions/interpretation: Glucose-stimulated insulin secretion; organelles involved in insulin secretion and gene expression were all affected by CVB replication in $\beta$ cells.

\section{INTRODUCTION}

Type 1 diabetes (T1D) is generally regarded to be caused by a specific autoimmune destruction of insulin-secreting $\beta$-cells. However, in addition to $\beta$-cell destruction and reduced $\beta$-cell mass, $\beta$-cell dysfunction has emerged as a possible contributor to the loss of insulin secretion, and subsequent $\beta$-cell death, which may enhance the immune response. Islets isolated from recent onset T1D organ donors have been found to have a decreased glucose-stimulated insulin secretion (GSIS), despite the presence of a large number of insulin-containing islets detected by immunohistochemistry (IHC). ${ }^{1-3}$ Islets from T1D donors can sometimes regain their function after a time of culture ex vivo ${ }^{1}$ and insulincontaining $\beta$-cells can be detected several decades postdiagnosis of T1D even in patients without detectable levels of $\mathrm{C}$ peptide. ${ }^{3-5}$

Development of T1D is to a large extent dependent on yet unknown factor(s). Human enterovirus (HEV) has for several decades been implicated in the pathogenesis of $\mathrm{T} 1 \mathrm{D},{ }^{6}$ both indirectly by frequent detection of immune responses against $\mathrm{HEV}$ in serum from patients with $\mathrm{T} 1 \mathrm{D},{ }^{7-9}$ and directly by demonstration of reactivity to EV-P1 by $\mathrm{IHC}^{1}{ }^{1011}$ or viral genome ${ }^{1213}$ in islets of T1D close to onset. A recent meta-analysis of studies detecting HEV with molecular methods showed a significant association between HEV infection and T1D. ${ }^{14}$ However, the causative relationship is still elusive and the mechanisms are unknown. Viruses with a lytic replication cycle and ability to replicate in $\beta$ cells impair the oscillations of cytoplasmic $\mathrm{Ca}^{2+}$ induced by glucose ${ }^{15}$ and reduce the glucose-stimulated release of insulin from the $\beta$ cells. ${ }^{16}$

Enterovirus replication results in the formation of a dsRNA intermediate in viral replication complexes formed in the cytoplasm by the virus. ${ }^{17-19} \mathrm{~A}$ model for enteroviral 
persistence has shown that the viral RNA can persist as dsRNA. ${ }^{20}{ }^{21}$ Synthetic dsRNA, poly(I:C), has been shown to affect $\beta$-cell function in rats ${ }^{22}$ and mice ${ }^{23}$ when the islets were exposed to interferon- $\gamma$, and to induce apoptosis in primary rat $\beta$ cells. ${ }^{24-26}$ The sensing of dsRNA in the cytoplasm results in an innate immune response in human islets. ${ }^{27}$ However, in contrast to poly(I:C), a virus infection leads to production of viral proteins that modulate the response of the infected cells to promote its own replication, resulting in a block of many of the pathways induced by poly(I:C).

The molecular mechanisms, by which host factors are involved in RNA-protein/protein-protein interaction, have been intensively studied; however, tissue-specific viral virulence remains unclear. Therefore, our aim was to study cellular function and ultrastructural changes in primary human cells in the islets of Langerhans.

\section{MATERIALS AND METHODS}

\section{Isolation and culture of human islets}

Human pancreases were obtained from 17 organ donors (6 females and 11 males) free of any known pancreatic disease, from transplantation units in Sweden, Norway, and Finland. All samples were analyzed anonymously. The donors used for analyses of islet function $(n=10)$ had an average age of $53 \pm 17$ years (range 20-73) and an average body mass index (BMI) of $25.4 \pm 1.9 \mathrm{~kg} / \mathrm{m}^{2}$ (range 22.2-27.8). The donors of islets used for gene expression analyses $(n=6)$ had an average age of $59 \pm 19$ (range 22-74) and an average BMI of $25.8 \pm 2.0 \mathrm{~kg} / \mathrm{m}^{2}$ (range 23.3-28.9). The donors used for IHC analysis $(n=1)$ and electron microscopic analysis $(n=1)$ had an age of 55 years and a BMI of $22.5 \mathrm{~kg} / \mathrm{m}^{2}$. Islets of Langerhans were isolated in Uppsala, Sweden, using a protocol approved by the Local Ethics Committee, as described previously. ${ }^{28}$ Only islet preparations with an intact GSIS were included in the study and the islets were available for research only because the total islet volume was too low for clinical transplantation. The islets were kept in culture bags (Baxter Medical AB, Sweden) with $200 \mathrm{~mL}$ CMRL-1066 (ICN Biomedicals, Costa Mesa, Californnia, USA) supplemented with $10 \mathrm{mM}$ HEPES, $2 \mathrm{mM}$ L-glutamin, $50 \mu \mathrm{g} / \mathrm{mL}$ Gentamycin, $0.25 \mu \mathrm{g} / \mathrm{mL}$ Fungizone (GIBCO BRL), $20 \mu \mathrm{g} / \mathrm{mL}$ Ciproxfloxacin (Bayer healthcare AG, Leverkusen, Germany), $10 \mathrm{mM}$ nicotinamide, and $10 \%$ heat-inactivated human serum at $37^{\circ} \mathrm{C}$ in $5 \%$ carbondioxide and humidified air for 1-5 days. The culture medium was changed on day 1 and then every other day until the islet experiments were performed.

\section{Virus}

Two strains of CVB4 (VD2921 and E2-Yoon) and two strains of CVB5 (Adr and V89-4557) were used. VD2921 (GenBank accession number AF328683) and V89-4557 were originally isolated from cerebrospinal fluid from patients with aseptic meningitis, ${ }^{16}{ }^{29-31}$ whereas $\mathrm{Adr}$
(GenBank accession number FJ374273) and E2-Yoon (GenBank accession number S76772) originate from patients at onset of type 1 diabetes and were isolated from stool and pancreas, respectively. ${ }^{6} 3233$

\section{Islet infection and observation of islet disintegration}

The isolated human islets had an estimated purity ranging from $40 \%$ to $95 \%$ (mean $69 \%$ ) and were purified further by hand-picking under a light microscope by islet experts. Forty hand-picked and size-matched islets per well were cultured in $2 \mathrm{~mL}$ RPMI-1640 containing $5.5 \mathrm{mM}$ glucose (SVA, Uppsala, Sweden) supplemented with $5 \%$ fetal bovine serum and $2 \mathrm{mM}$ L-glutamine, in 6-well plates for suspension cells (Sarstedt AB, Helsingborg, Sweden). Hand-picked islets were cultured for 24 hour before inoculation with CVB (CVB5/Adr, CVB5/V89-4557, CVB4/E2-Yoon, or CVB4/VD2921) to a final concentration of 100-1000 TCID50. Forty islets from each donor were exposed to $50 \mu \mathrm{g} / \mathrm{mL}$ synthetic dsRNA (Poly(I:C), Sigma-Aldrich Sweden AB, Stockholm, Sweden). Samples of culture medium were collected from all wells, directly after inoculation and every day until days 4-7 postinfection, and stored at $-20^{\circ} \mathrm{C}$ for subsequent $\mathrm{TCID}_{50}$ titrations. Inoculated and uninoculated islets from the same donor were observed every day in a light microscope. The appearance of virus-induced islet disintegration was graded from $1+$ to $4+$ as previously described, ${ }^{29}$ until the experiments were terminated on days 4-7 postinfection. Islets exposed to poly(I:C) and unexposed control islets were cultured for 24 hour before termination of the experiment. On termination, islets were washed twice with phosphatebuffered saline and challenged with high glucose in a dynamic perifusion assay or stored in RNA later (Qiagen $\mathrm{AB}$, Sollentuna, Sweden) for subsequent analyses.

\section{Islet function test}

GSIS of CVB-infected, poly(I:C)-exposed, and control islets was assessed in a dynamic perifusion system, Suprafusion 1000 (BRANDEL, Gaithersburg, Maryland, USA). Islets were perifused with two glucose concentrations $(1.67$ and $20 \mathrm{mM}$ and then $1.67 \mathrm{mM})$. Fractions were collected at $6 \mathrm{~min}$ interval for $120 \mathrm{~min}$ and insulin concentrations were determined by ELISA (Mercodia, Uppsala, Sweden). Insulin secretion at each time point was normalized to control islets from the same donor, and is expressed as percent secretion compared to the first phase peak of the respective untreated control.

\section{Analysis of virus replication}

Virus replication was determined by tissue culture infectious dose $_{50}\left(\mathrm{TCID}_{50}\right)$ titrations of samples of culture medium on an in-house cell line originating from Green Monkey Kidney cells, obtained from Gothenburg University, Sweden, as described previously. ${ }^{34}$ The samples were collected from the infected islet cultures on the indicated days pi. 


\section{RNA extraction and real-time RT-PCR}

Total RNA from explained islets stored in RNA later, was extracted with RNeasy Plus Mini kit (Qiagen AB, Sollentuna, Sweden). RNA quantity and quality were determined using spectrophotometry and gel electrophoresis. Up to $50 \mathrm{ng}$ total RNA per sample were primed with Random Primers (Invitrogen) and reverse transcribed to cDNA with SuperScript II RT (Invitrogen) according to the manufacturer's instructions. Control reactions containing all reagents except the reverse transcriptase were included to confirm the absence of interfering genomic DNA. RNaseOUT (Invitrogen) was added to the reaction to avoid RNA degradation. Real-Time PCRs were run with Power SYBR Green master mix (Applied Biosystems, Sweden) on a StepOnePlus Real-Time PCR system (Applied biosystems, Sweden). Predesigned gene-specific primer sets (QuantiTect Primer Assays, Qiagen) were used for detection of insulin, glucagon, glut-1 (SLC2A1), glut-2 (SLC2A2), mafA, mafB, and PDX1 cDNA. The expression level of each gene was normalized against expression of the reference gene $18 \mathrm{~S}\left(2^{-\Delta \mathrm{Ct}}\right)$, and is presented as fold induction compared to untreated islets from the same donor $\left(2^{-\Delta \Delta \mathrm{Ct}}\right)$. PCR specificity was verified by melt curve analysis of all PCR products.

\section{Immunohistochemistry}

Islets from a representative donor infected with CVB5/ V89-4557 or CVB4/E2-Yoon resulting in moderate islet disintegration (graded 2+ to 3+) and mock-infected control islets were fixed in 4\% PFA and paraffinembedded day six postinoculation. Sections $(5 \mu \mathrm{m})$ were dried on SuperFrost slides (Menzel Gläser, Braunschweig, Germany), followed by deparaffination and rehydration in xylene and decreasing concentrations of ethanol, respectively. Endogenous peroxidase was blocked for $10 \mathrm{~min}$ followed by incubation of primary antibodies (guinea-pig anti-insulin 1:200) in a humidified chamber at $37^{\circ} \mathrm{C}$. Washing steps were performed in TBS with $0.05 \%$ Tween 20. Visualization was achieved by Envision using $\mathrm{DAB}$ as a substrate chromogen. All reagents and antibodies were purchased at DAKO, Glostrup, Denmark.

\section{Electron microscopy}

Isolated pancreatic islets from one donor were either inoculated with CVB5/Adr to a final concentration of $5.5 \mathrm{TCID}_{50}$ or left uninoculated. On day three postinfection, all islets were fixed in $2 \%$ glutaraldehyde in $0.1 \mathrm{M}$ cacodylate buffer supplemented with $0.1 \mathrm{M}$ sucrose, followed by 1.5 hour postfixation in $1 \% \mathrm{OsO}_{4}$, dehydration, and embedding in epoxy plastic Agar 100 (Agar Aids, , Stansted, England). Ultrathin sections $(50 \mathrm{~nm})$ were placed on Formvar-coated Cu-grids and contrasted with uranyl acetate and lead citrate. The ultrastructural morphology was analyzed in an electron microscope (Tecnai $\mathrm{G}^{2}$ Spirit BioTWIN). Subsequently, representative islets were analyzed by large-scale $\mathrm{EM}^{35}$ on a Zeiss Supra55 (Germany) with an external large-scan generator (ATLAS,
Fibics, Canada) at 29kv; 2nm pixel-size-using the STEM detecor.

http://www.nanotomy.org/OA/Hodik2016DRC/

Quantification of the insulin granule-, lipofuscin- and mitochondrial cytoplasmic area $(\%)$ was made on the outer layer of cells on cross-sections of both CVB-5/Adr infected and uninoculated control islets. Lipofuscins were defined as secondary lysosomes with electronlucent (ie, lipid-like material) vesicles $^{36}$ and insulin granules after the irregular crystalline electron-dense core in an electron-transparent halo. ${ }^{37}$ The organelles were manually color-coded in Photoshop CS4 and analyzed with Fuji32/ImageJ using the color deconvolution tool. Lipofuscin, insulin, and mitochondrial analyses were performed on virus-particle-containing $\beta$ cells $(n=11), \beta$ cells with no signs of infection $(n=7)$, and noninoculated $\beta$ cells in the periphery of the islet $(n=11)$. The density of insulin granules was analyzed in the same cells.

\section{Statistical analysis}

Differences in insulin secretion and gene expression levels were analyzed with Wilcoxon matched-pairs signed rank test. Ultrastructural quantitative data were analyzed with Mann-Whitney two-tailed tests. $p$ Values $<0.05$ were considered statistically significant. Data values are presented as mean \pm SEM.

\section{Ethics statement}

The work performed on human tissue was in accordance with the principles expressed in the Declaration of Helsinki and the European Council's Convention on Human Rights and Biomedicine. The study was approved by the Regional Ethics Committee in Uppsala, Sweden according to the Act concerning the Ethical Review of Research Involving Human (2003:460), Permit Number: Dnr 2009/043, 2009/371 and Ups 02-577. The pancreas was obtained from the Nordic Network of Islets transplantation.

\section{RESULTS}

Virus-induced islet disintegration decreases GSIS in human islets

The level of replication and degree of islet disintegration varied between the different virus strains and islet donors (table 1$)$. In six cases $(n=6)$, the virus had replicated (mean titer increase $3.1 \quad \log \mathrm{TCID}_{50} / 200 \mu \mathrm{L}$ ) without causing any observable islet disintegration (table 1). Despite viral replication, GSIS in these islets was not significantly different compared to that of the noninoculated control islets (figure 1A). When a low but clear (graded $1+$ to $2+$ ) virus-induced islet disintegration was observed along with a mean titer increase of 3.7 $\log \operatorname{TCID}_{50}(\mathrm{n}=6$; table 1$)$, the rapid first as well as sustained second phase of GSIS was slightly decreased compared to non-inoculated islets $(\mathrm{p}<0.05)$. The basal insulin release at low $(1.67 \mathrm{mM})$ glucose was not altered 
Table 1 Virus replication and virus-induced islet disintegration in different donors

\begin{tabular}{|c|c|c|c|}
\hline Donor number & $\begin{array}{l}\text { Strain of CVB } \\
\text { (day of termination) }\end{array}$ & $\begin{array}{l}\text { Islet disintegration* } \\
\text { (graded from } 0 \text { to } 4 \text { ) }\end{array}$ & $\begin{array}{l}\text { Titer change } \\
\text { from day } 0\end{array}$ \\
\hline \multirow[t]{2}{*}{1} & Adr (6 dpi) & 0 & +4 \\
\hline & V89-4557 (6 dpi) & $3-4$ & +4 \\
\hline \multirow{3}{*}{2} & VD2921 (4 dpi) & 0 & +3 \\
\hline & V89-4557 (4 dpi) & 0 & +2.5 \\
\hline & V89-4557 (7 dpi) & 3 & +4.5 \\
\hline \multirow[t]{2}{*}{3} & Adr (7 dpi) & 0 & +3.5 \\
\hline & VD2921 (7 dpi) & 0 & +3.5 \\
\hline \multirow[t]{2}{*}{4} & E2-Yoon (7 dpi) & 3 & +3 \\
\hline & VD2921 (7 dpi) & 2 & +6 \\
\hline \multirow[t]{3}{*}{5} & E2-Yoon (4 dpi) & 2 & +1.5 \\
\hline & E2-Yoon (7 dpi) & $3-4$ & +2 \\
\hline & V89-4557 (7 dpi) & 2 & +2.5 \\
\hline 6 & E2-Yoon (6 dpi) & $3-4$ & +2.5 \\
\hline 7 & E2-Yoon (6 dpi) & 0 & +2 \\
\hline 8 & E2-Yoon (6 dpi) & 3 & +2.5 \\
\hline \multirow[t]{3}{*}{9} & VD2921 (6 dpi) & 2 & +4.5 \\
\hline & V89-4557 (6 dpi) & $3-4$ & +4 \\
\hline & E2-Yoon (6 dpi) & $3-4$ & +3 \\
\hline \multirow[t]{3}{*}{10} & VD2921 (6 dpi) & 2 & +5 \\
\hline & V89-4557 (6 dpi) & $3-4$ & +6 \\
\hline & E2-Yoon (6 dpi) & 2 & +2.5 \\
\hline
\end{tabular}

(figure 1B). Pronouncedly disintegrated islets (graded 3-4) and mean titer increase $3.6 \operatorname{logTCID}_{50}$ (table 1$)$ showed poor or none GSIS $(n=9, p<0.05)$ (figure $1 \mathrm{C}$ ).

There were no difference in GSIS between the virus strains, but that might be due to the limited number of analyses, due to the limited number of islets available.

\section{Synthetic dsRNA potentiates GSIS in human islets}

Islets exposed to poly(I:C) showed a potentiated response to high glucose (figure $2 \mathrm{~A} ; \mathrm{p}<0.05$ ); the rapid first phase of insulin release was increased 2.5-fold compared to that of untreated control islets, and the sustained second phase was about doubled. At low $(1.6 \mathrm{mM})$ glucose, the insulin release was similar in islets exposed to poly(I:C) and untreated control islets.

A dose-response relationship could be observed when GSIS was tested with dynamic glucose perifusion 24 hour after poly(I:C) exposure, where $10 \mu \mathrm{g} / \mathrm{mL}$ had no effect, $50 \mu \mathrm{g} / \mathrm{mL}$ had moderate effect and $250 \mu \mathrm{g} / \mathrm{mL}$ had the strongest effect (figure $2 \mathrm{~B} ; \mathrm{n}=1$ ). Four days after exposure to 250 or $50 \mu \mathrm{g} / \mathrm{mL}$ poly(I:C), the islets were still strongly potentiated to release insulin in response to high glucose compared to control islets, but no difference could be seen between these two concentrations (figure $2 \mathrm{C} ; \mathrm{n}=1$ ).

\section{Virus-induced islet disintegration correlates specifically to reduced transcription of islet genes}

Six days postinfection, islets infected with CVB4/VD2921 showed moderate islet disintegration (graded 2+), which was more pronounced (graded $3+$ to $4+$ ) in islets infected with CVB4/E2-Yoon or CVB5/V89-4557. The relative islet expression of insulin mRNA was reduced in all islets with virus-induced disintegration (figure $3 \mathrm{~A}$ ), whereas the relative expression of glucagon mRNA was unaffected by infection with CVB4/E2-Yoon or CVB4/ VD2921 (figure 3B). The third virus strain, CVB5/ V89-4557, reduced the relative islet expression of both insulin and glucagon mRNA (figure 3A, B). Expression of the two transcription factors $p d x 1$ and mafa was also reduced to a similar extent by infection with the three viruses, whereas mafb (mainly expressed in $\alpha$ cells ${ }^{38}$ ) was only reduced by CVB5/V89-4557 infection (figure 3C-E). The expression of mRNA encoding the glucose transporter protein glut2 was downregulated by the three viruses to a similar extent as the expression of ins, mafa, and $p d x 1$ (figure 3G). The expression of the gene encoding glut1 was not affected by virus infection, except in islets infected with CVB5/V89-4557 in which it was upregulated significantly (figure $3 \mathrm{~F}$ ). Exposure of islets to poly $(\mathrm{I}: \mathrm{C})$ did not affect the expression of any of these genes (figure $3 \mathrm{~A}-\mathrm{G}$ ).

\section{Insulin is detected immunohistochemically and ultrastructurally in disintegrated infected islets with decreased or lost GSIS}

Insulin was detected by IHC in CVB-infected islets with a degree of virus-induced disintegration (graded $2+$ to $3+$ ) and unresponsiveness to $20 \mathrm{mM}$ glucose (figure $4 \mathrm{~A}$ ). Ultrastructural analysis confirmed the presence of 

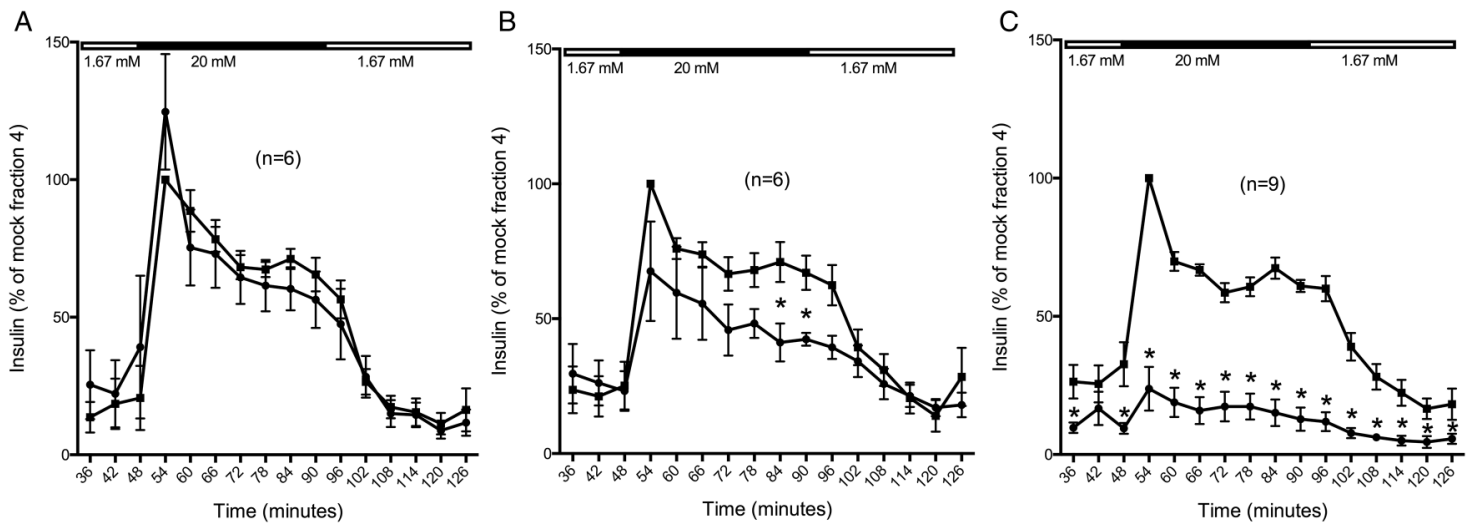

Figure 1 Glucose-stimulated insulin secretion in virus-infected human islets. Forty hand-picked and size-matched human islets from each donor were inoculated with serotypes/strains of CVB (black circles) or uninoculated (black boxes; medium only). On days four to seven postinoculation, the islets were perifused with low glucose $(1.67 \mathrm{mM})$ for $42 \mathrm{~min}$, high glucose $(20 \mathrm{mM})$ for $48 \mathrm{~min}$, and then low glucose again. Fractions were collected at $6 \mathrm{~min}$ intervals and the secreted insulin was measured by ELISA. Islets were grouped based on the virus-induced islet disintegration in three groups: no visible disintegration (A), moderate disintegration (B), and pronounced disintegration (C). ${ }^{*} p<0.05$. CVB, coxsackievirus.
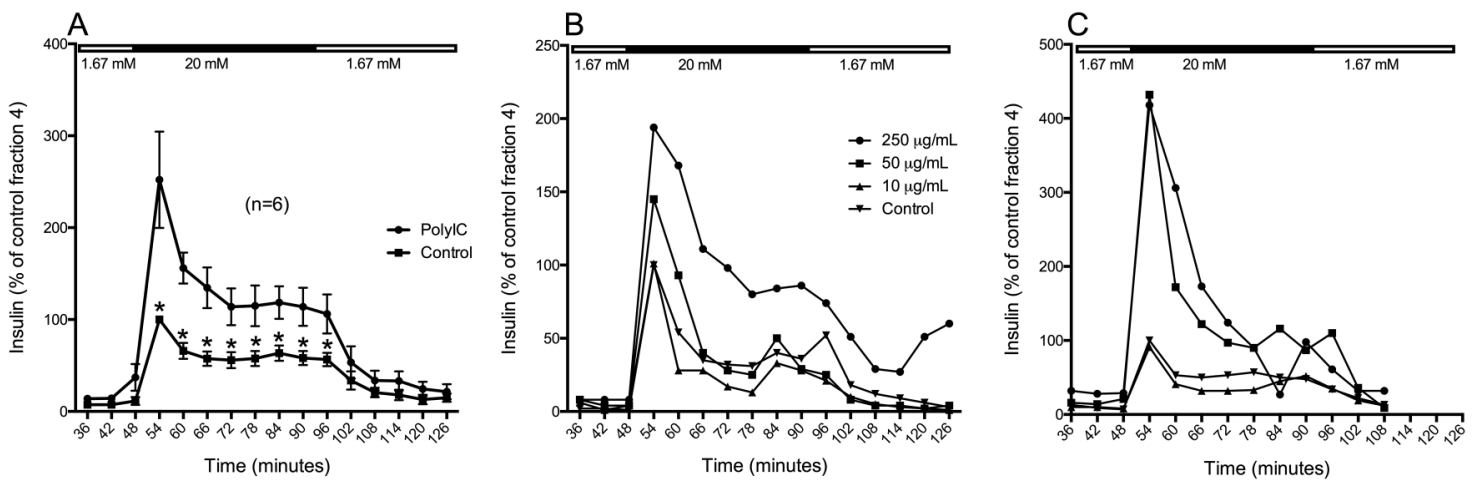

Figure 2 Glucose-stimulated insulin secretion in human islets exposed to poly(l:C). Forty hand-picked and size-matched human islets were exposed to poly $(\mathrm{l}: \mathrm{C})$ or left untreated. 24 hour $(\mathrm{A}, \mathrm{B})$ or 96 hour $(\mathrm{C})$ postexposure, the islets were perifused with low glucose $(1.67 \mathrm{mM})$ for $42 \mathrm{~min}$, high glucose $(20 \mathrm{mM})$ for $48 \mathrm{~min}$, and then low glucose again. Fractions were collected at $6 \mathrm{~min}$ intervals and the secreted insulin was measured by ELISA. Mean insulin secretion in islets exposed to $50 \mu \mathrm{g} / \mathrm{mL}$ poly(l:C) was measured after 24 hour $(A)(n=6)$. Insulin secretion in islets exposed to 250,50 , or $10 \mu \mathrm{g} / \mathrm{mL}$ poly(l:C) was measured after 24 hour $(B)$ or 96 hour $(C)(n=1)$. ${ }^{*}<<0.05$.

insulin granules in CVB5/Adr-infected $\beta$ cells in various necrotic stages (figure $4 \mathrm{~B}$ ).

\section{Virus-induced ultrastructural changes can be seen in $\beta$ cells in moderately disintegrated islets}

Islets from five donors were inoculated and analyzed for the presence of virus particles, viral replication complexes, and virus-induced ultrastructural changes. Two representative islets from one donor were selected for large-scale electron microscopy $(\mathrm{EM})$ to evaluate if this could be used for quantitation. Both infected and uninfected islets lacked basal lamina, due to the isolation process, although the plasma membranes and the different cell to cell contacts were normal. Infected islets had an irregular outer form, in line with the findings in the light microscopy studies, due to detachment of dead cells. Virus particles were found in $\beta$ cells in the outermost cell layers of the islet, assembled in one or several crystal rafts scattered in the cytoplasm (figure $5 \mathrm{~A})$. The finding of virus particles only in $\beta$ cells of the islets, 3 days postinfection, can be explained by the lack of basal lamina resulting in virus infecting the first layer of cells and the released progeny virus that will bind to and infect the next layer of $\beta$ cells. Occasionally, empty viral capsids were observed in the viral rafts (figure $5 \mathrm{~B}$, black arrow). In infected $\beta$ cells, nuclei were condensed with invaginations and marginated condensed chromatin. Endoplasmic reticulum (ER) was dilated with dropped off ribosomes and often broken up into small vesicles and vacuoles. Golgi apparatuses were also decomposed into vesicles and vacuoles of various electron densities (figure 5C, D). In virus-infected $\beta$ cells $(n=11)$, no recognizable Golgi apparatus was observed compared to apparently non-infected $\beta$ cells $(n=7)$ in 

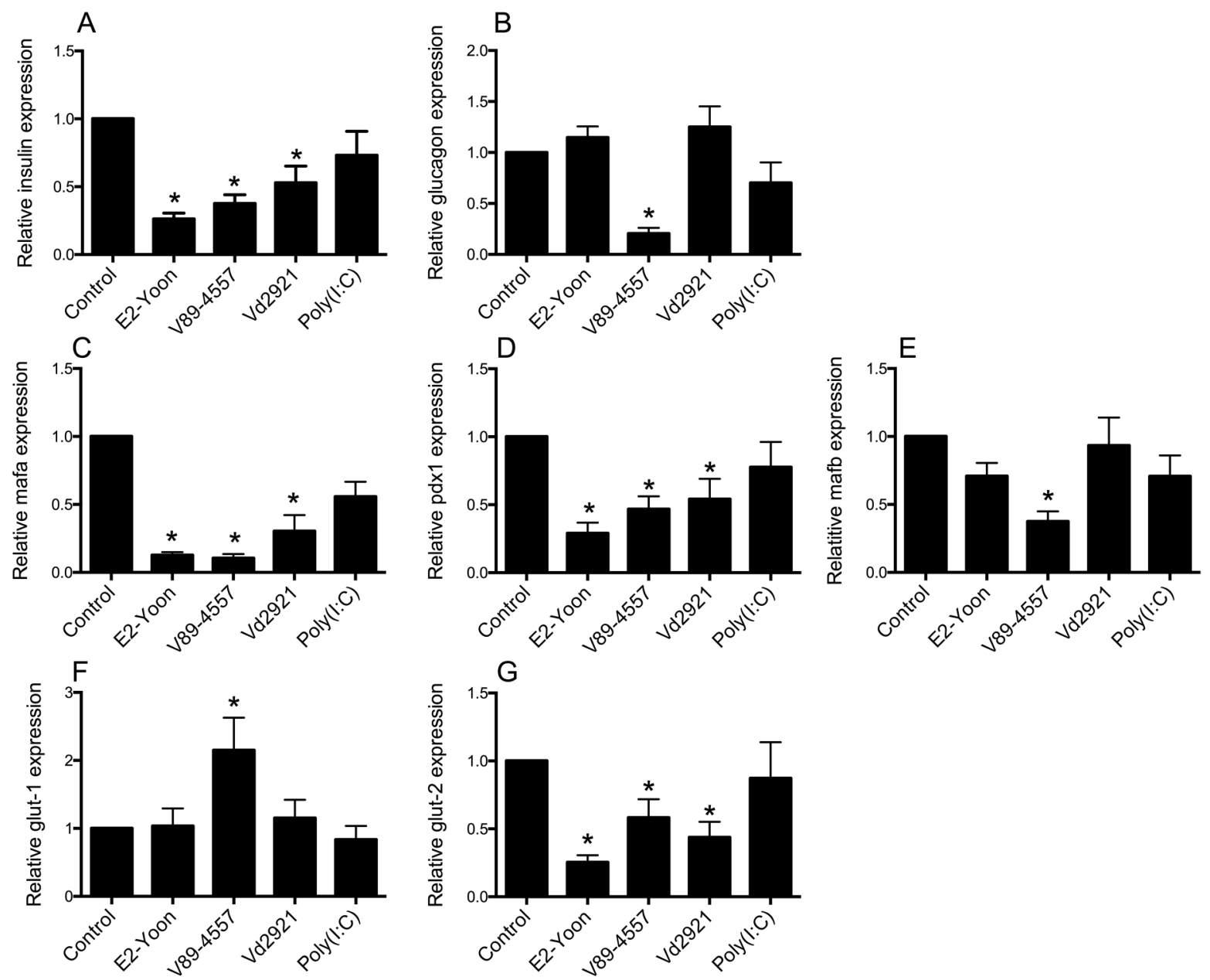

Figure 3 Islet mRNA expression of insulin (A), glucagon (B), mafa (C), pdx1 (D), mafb (E), glut-1 (F), and glut-2 (G). Forty hand-picked islets were exposed to $50 \mu \mathrm{g} / \mathrm{mL}$ poly(l:C), inoculated with CVB4/E2-Yoon, CVB5/V89-4557, or CVB4/VD2921 or left untreated. Six days postinfection, or 1 day postexposure to poly(l:C), the intracellular mRNA content was measured by qPCR. The gene specific expression relative to expression of the reference gene $18 \mathrm{~S}$ was normalized to the expression in mock-infected control islets from the same donor $\left(2^{\wedge}-\Delta \Delta C t\right)$. Data are expressed as mean \pm SEM from experiments on six different islet donors $(n=6) .{ }^{*} p<0.05$. CVB, coxsackievirus.
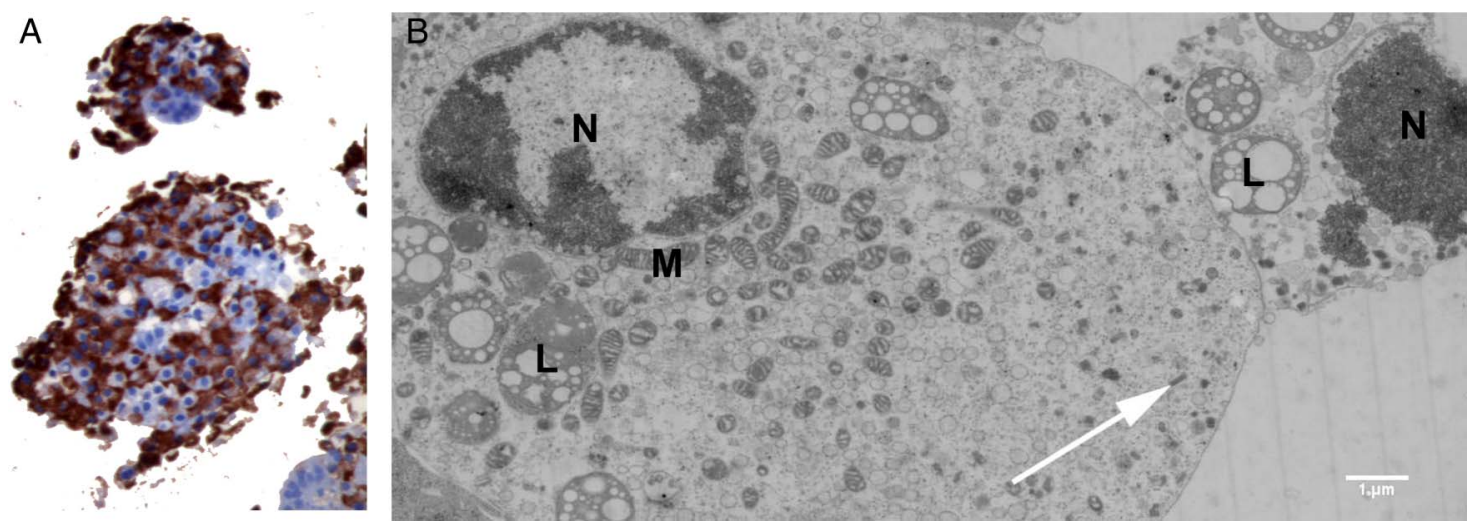

Figure 4 Representative images of human islets infected with strains of CVB. (A) Immunohistochemical staining of insulin in islets infection with CVB5/V89-4557 6 days postinfection. Original magnifications $\times 20$. (B) Electron micrograph of $\beta$-cells in different stages of necrosis in CVB5/Adr inoculated islet, showing presence of insulin (white arrows). CVB, coxsackievirus; M, mitochondria, N, nuclei, L, lipofuscin. 

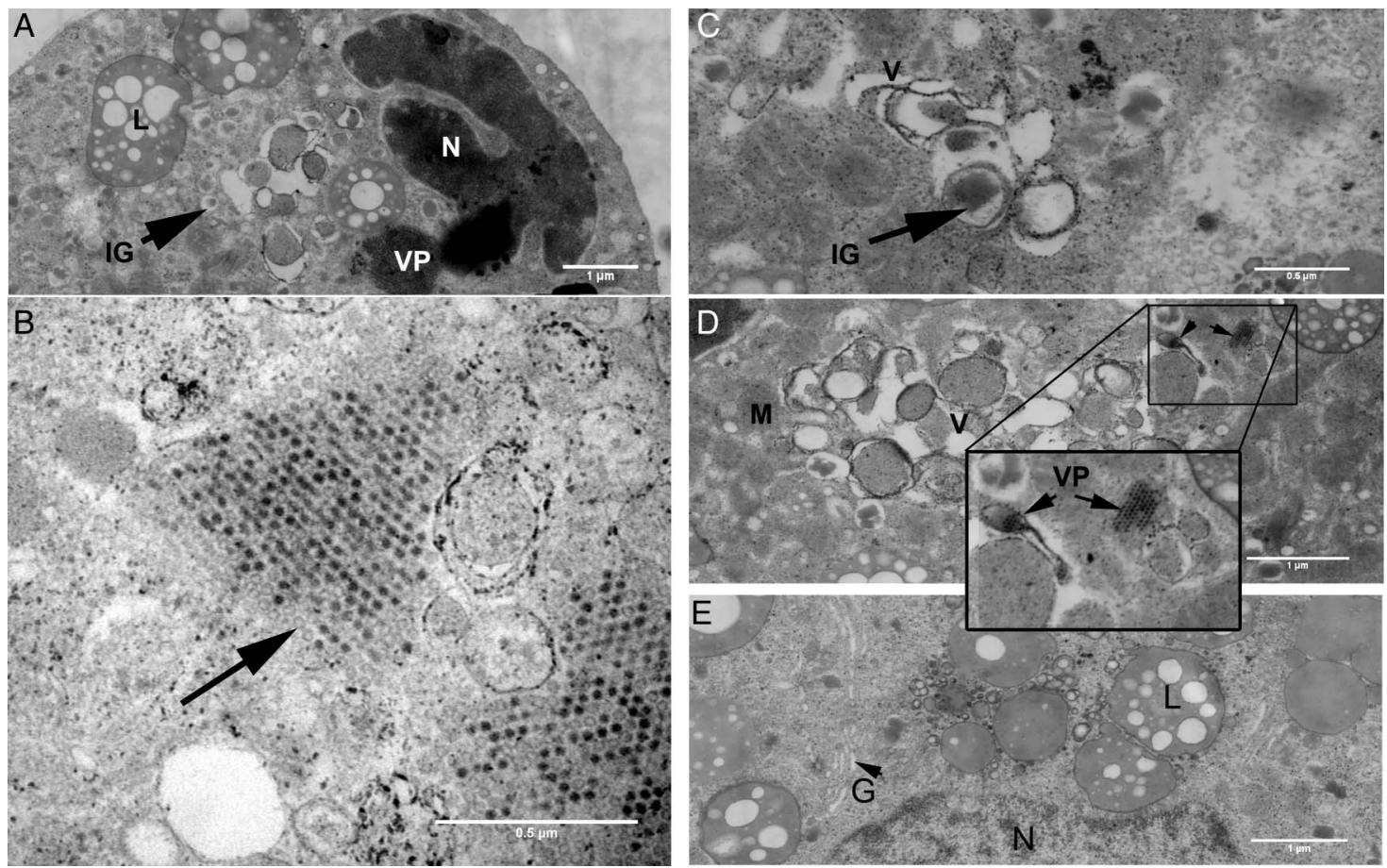

Figure 5 Ultrastructural analysis of islet infected with a strain of CVB. (A) Infected $\beta$-cell with virus particles and a condensed and invaginated nucleus. CVB, coxsackievirus; IG, insulin granule; L, lipofuscin; N, nucleus, VP, virus particles,. (B) Empty-virus capsids (arrow) (C and D) Virus-induced vesicular and vacuolar structures of varying complexity. CVB, coxsackievirus; IG, insulin granule; M, mitochondria; V, vesicles and vacuoles. Inset: VP at higher magnification. (E) Recognizable Golgi complexes (G) in $\beta$-cell with no signs of virus infection and normal nuclei $(N)$ in an infected islet. L, lipofuscin. (F) Upper row from left: Cytoplasmic insulin area (\%), insulin granule density (insulin granules $/ \mathrm{um}^{2}$ ), and observed insulin granule diameter (nm). Lower row from the left: Mitochondrial area (\%) and lipofuscin area (\%). Bars correspond to \pm SEM. In figure $5 \mathrm{~F}$, quantification of insulin granules, area of lipofuscin and mitocondria. Number of insulin granules (insulin granules/ $\mathrm{m}^{2}$ ) and cytoplasmic insulin, lipofuscin and mitochondrial area (\%) in CVB infected $(n=11)$, no signs of virus infection $(n=7)$ and uninfected $(n=11) \beta$-cells. Bars correspond to \pm SEM. CVB, coxsackievirus B.

the same islet in which well-developed Golgi apparatuses were observed in $\sim 71 \%$ of cells (figure $5 \mathrm{E}$ ). In infected $\beta$ cells, the ultrastructure of mitochondria were apparently normal with well-preserved cristae. In severely decomposed $\beta$ cells also, the mitochondria started to condense (figure 4B).

The cross-section of a whole non-inoculated islet and a CVB5/Adr-infected islet displayed $\sim 76 \%$ and $\sim 40 \% \beta$ cells, respectively. Virus particles were found in $\sim 16 \%$ of the $\beta$ cells $(n=11)$ in the CVB5/Adr-infected islet periphery, and signs of virus infection were observed in $\sim 80 \%$ of the $\beta$ cells. The insulin granule-, lipofuscin- and mitochondrial cell area and insulin granule density quantification comparison between infected islet and uninfected control islet was performed on the outer cell layers. Other endocrine cell types present in the same islet were unaffected by the virus infection even when surrounded by virus-infected $\beta$ cells. Cytoplasmic insulin granule (IG) area (\%) and IG density $\left(\mathrm{IG} / \mu \mathrm{m}^{2}\right)$ were significantly higher in CVB-5/Adr-infected $\beta$ cells with virus particles $\left(10.7 \pm 1.17 \%\right.$ and $\left.3.2 \pm 0.35 \mathrm{IG} / \mu \mathrm{m}^{2} ; \mathrm{n}=11\right)$ compared to peripheral $\beta$ cells in a non-inoculated islet $\left(4.4 \pm 0.63 \%\right.$ and $1.5 \pm 0.22 \mathrm{IG} / \mu \mathrm{m}^{2} ; \mathrm{n}=11$ ) (figure $5 \mathrm{~F}$ ). The IG area, but not the IG density, was also significantly higher in CVB-5/Adr-infected $\beta$ cells with virus particles than in $\beta$ cells without visible virus particles in the same islet $\left(6.1 \pm 0.8 \%\right.$; and $2.6 \pm 0.36 \mathrm{IG} / \mu \mathrm{m}^{2} ; \mathrm{n}=7$ ) (figure $5 \mathrm{~F}$ ). The observed mean IG diameter was significantly higher in the islet peripheries both in virus-infected $\beta$ cells (209 $\pm 8.7 \mathrm{~nm} ; \mathrm{n}=11)$ and non-inoculated $\beta$ cells (194 \pm 8.6 ; $\mathrm{n}=11$ ) compared to apparently uninfected $\beta$ cells in the infected islet $(175 \pm 3.8 \mathrm{~nm} ; \mathrm{n}=7$ ) (figure $5 \mathrm{G})$. There was no statistical difference in cytoplasmic mitochondrial and lipofuscin cytoplasmic area between infected and non-inoculated cells (figure $5 \mathrm{H}$ ).

\section{DISCUSSION}

Here, we demonstrate that virus-induced disintegration of human islets leads to reduced GSIS and decreased expression of the $\beta$ cell specific genes encoding insulin, mafA, pdxq, and glut2. These results correlate well with the sign of virus infection only in $\beta$ cells revealed by ultrastructural analysis. In infected $\beta$ cells, the Golgi apparatuses are resolved, and nuclei with deep invaginations and condensed chromatin, indicating various stages of virus-induced cell death, can be seen.

The degree and kinetics of virus-induced islet disintegration varied between the different strains of CVB, as well as between islets from different donors (table 1). 
Non-disintegrated islets or islets with low-grade disintegration with a high viral titer increase and no effect on GSIS could contain more $\beta$ cells or the time from infection to cell death might be longer compared to that in highly disintegrated islets. In islets that were only moderately disintegrated (grade $2+$ to $3+$ ), it was shown that $\sim 80 \%$ of the $\beta$ cells had signs of infection, though the effect on islets function was less pronounced, suggesting that the remaining and non-infected $\beta$ cells to some extent compensate for the loss.

The finding that infected $\beta$ cells contain somewhat larger insulin granules compared to non-infected $\beta$ cells from the same islet might be due to accumulation of cholesterol to replication sites by viral proteins. ${ }^{39}$ Cholesterol accumulation has been shown to increase insulin granule size and also to impair membrane trafficking. ${ }^{40}$

Accumulation of the viral protein $2 \mathrm{~B}$ or $2 \mathrm{BC}$ on the Golgi apparatus changes the permeability of these membranes $^{41}$ and causes disassembly of the Golgi apparatus ${ }^{42}$ and ultimately lysing cells, halting insulin secretion. In addition, in virus infected cells, the membrane that integrates the 2B/2BC complex also reduces the $\mathrm{Ca}^{2+}$ levels in the $\mathrm{ER} ;{ }^{43-45}$ this is also related to antiapoptotic properties. ${ }^{46}$ The effect of virus infection on cholesterol accumulation and on $\mathrm{Ca}^{2+}$ concentrations will affect GSIS.

It is also known that these viruses cleave the translation initiation factor eIF4GI, which leads to block of capdependent translation; ${ }^{46}$ this will result in transcription of IRES containing sequences such as the viral genome and cellular IRES containing genes such as bcl-2 and bip. Recently, it was shown that the major part of the synthesis of insulin is cap-dependent, ${ }^{47}$ suggesting that in an enterovirus infected $\beta$ cells this would eventually lead to hampered insulin secretion.

In support of our findings, it has been shown that an increase in intracellular insulin content has been implicated in HEV-infected islets, suggesting that a block of secretion might precede the block of translation. ${ }^{16}$

Our finding that virus particles only can be detected in $\beta$ cells might be explained by the fact that HEVs have been shown to translocate key proteins in the secretory pathway, including adenosine diphosphate (ADP) ribosylation factor 1 (ARF1) and its activator, Golgi-specific brefeldin A-resistance guanine nucleotide exchange factor 1 (GBF1) to virus-induced replication membranes. Interestingly, the GBF1 protein, which is crucial for virus replication, is expressed specifically in $\beta$ cells, and that could be one explanation for the predominant virus replication in these cells. ${ }^{48}$

The mitochondria in severely decomposed cells have condensed but well-discernible cristae, which are signs of an actively respiratory state and this have been observed in apoptosis and autophagy; ${ }^{49}{ }^{50}$ both these cell death pathways have previously been implicated in enterovirus-infected cells. ${ }^{25} 51$

The finding that the expression of insulin but not glucagon mRNA was lower in islets infected with E2-yoon or VD2921 than in uninfected control islets supports previous studies arguing for a selective tropism of many HEV for $\beta$ cells. ${ }^{1}{ }^{10}{ }^{12}$ Ultrastructural analysis supported this notion; virus particles were only seen in $\beta$ cells. In islets infected with the V89-4557 strain, both the transcription of glucagon and insulin was reduced in contrast to in islets infected with other CVB strains. In contrast to most other CVB serotypes/strains, this virus has previously been shown to infect cells lacking both CAR and $\mathrm{DAF}^{30}$ giving it a broader tropism. Perhaps this strain also has tropism for $\alpha$ cells. Interestingly, the relative expression of glut 1 was increased significantly in islets infected with this virus strain, perhaps reflecting high expression of glut1 in a non-permissive islet celltype, but this needs to be investigated further.

The ideal thing would have been to infect islets with all strains and study them with an external large-scan generator (ATLAS, Fibics, Canada); however, this was not possible to do due to practical and logistical reasons. It should be stressed that all strains were studied with EM (some in previous publications), but the purpose of this study was to see if the ultrastructural changes that could be seen in islet cells containing virus particles could be quantitated and that on a whole islet basis to where the virus could be seen, and if similar ultrastructural changes could be seen in islet cells with no visible virus particles. We have shown that the method works and it can now be used to study the effect of virus infections, toxins, etc.

Synthetic dsRNA (poly(I:C)) potentiated GSIS in human islets. This is in contrast to findings in murine islets where synthetic dsRNA alone has no effect on GSIS. poly(I:C) exposure of interferon- $\gamma$-treated murine islets, induced apoptosis and reduced GSIS. ${ }^{22-26}$ The viral dsRNA could not increase GSIS, probably because the virus infection causes reduced $\mathrm{Ca} 2+$ levels, indicating that poly(I:C) is not a good model for viral infections.

In summary, the data presented here show that CVB infection can impair $\beta$ cell function and $\beta$ cell specific gene expression. The decreased GSIS in the virus-infected and disintegrated islets is most likely due to a functional loss of virus infected and dispersed cells, whereas non-infected $\beta$ cells in islets with low-grade disintegration probably still can secrete insulin in response to glucose stimulation. The functional loss of the infected $\beta$ cells is supported by the loss of the Golgi apparatus and the condensed chromatin. The $\beta$ cell specific expression of GFB1, an essential protein for CVB replication, might explain why virus particles are only detected in these cells.

Acknowledgements The authors acknowledge The Nordic Network for Clinical Islet Transplantation for the supply of pancreas/islets.

Contributors BNGG and JK performed and analyzed nanotomy. MH and OS infected islets and performed EM, GISIS, and gene expression analyses. All authors analyzed the data and edited the manuscript.

Funding This study was supported by grants from EU-FP7-Health 2010 PEVNET 261441, the Diabetes Research and Wellness Foundation Non-Clinical Research Fellowship, Barndiabetesfonden (The Swedish Child 
Diabetes Foundation), JDRF nPOD-V, Diabetesfonden (the Swedish Diabetes Association), the Swedish Medical Research Council (65X-12219-15-6), the Swedish national strategic research initiative EXODIAB (Excellence Of Diabetes Research in Sweden) and the National Institutes of Health (2U01AI065192-06). The Netherlands Organisation for Scientific Research, ZonMW91111006. Part of the work has been performed in the UMCG Microscopy and Imaging Center (UMIC), sponsored by ZonMW grant 91111.006.

\section{Competing interests None declared.}

Provenance and peer review Not commissioned; externally peer reviewed.

Data sharing statement All nanotomy data are available at full resolution via http://www.nanotomy.org on acceptance of the paper, for review purposes it is password protected available.

Open Access This is an Open Access article distributed in accordance with the Creative Commons Attribution Non Commercial (CC BY-NC 4.0) license which permits others to distribute, remix, adapt, build upon this work noncommercially, and license their derivative works on different terms, provided the original work is properly cited and the use is non-commercial. See: http:// creativecommons.org/licenses/by-nc/4.0/

\section{REFERENCES}

1. Dotta F, Censini S, van Halteren AG, et al. Coxsackie B4 virus infection of beta cells and natural killer cell insulitis in recent-onset type 1 diabetic patients. Proc Natl Acad Sci USA 2007;104:5115-20.

2. Gianani R, Campbell-Thompson M, Sarkar SA, et al. Dimorphic histopathology of long-standing childhood-onset diabetes. Diabetologia 2010;53:690-8.

3. Coppieters KT, Dotta F, Amirian N, et al. Demonstration of islet-autoreactive CD8T cells in insulitic lesions from recent onset and long-term type 1 diabetes patients. J Exp Med 2012;209:51-60.

4. Keenan HA, Sun JK, Levine J, et al. Residual insulin production and pancreatic ss-cell turnover after 50 years of diabetes: Joslin Medalist Study. Diabetes 2010;59:2846-53.

5. Liu EH, Digon BJ III, Hirshberg B, et al. Pancreatic beta cell function persists in many patients with chronic type 1 diabetes, but is not dramatically improved by prolonged immunosuppression and euglycaemia from a beta cell allograft. Diabetologia 2009;52:1369-80.

6. Yoon JW, Austin M, Onodera T, et al. Isolation of a virus from the pancreas of a child with diabetic ketoacidosis. $N$ Engl J Med 1979;300:1173-9.

7. King ML, Shaikh A, Bidwell D, et al. Coxsackie-B-virus-specific lgM responses in children with insulin-dependent (juvenile-onset; type I) diabetes mellitus. Lancet 1983;1:1397-9.

8. Gamble DR, Kinsley ML, FitzGerald MG, et al. Viral antibodies in diabetes mellitus. Br Med J 1969;3:627-30.

9. Frisk G, Fohlman J, Kobbah M, et al. High frequency of Coxsackie-B-virus-specific IgM in children developing type I diabetes during a period of high diabetes morbidity. J Med Virol. 1985;17:219-27.

10. Richardson SJ, Willcox A, Bone AJ, et al. The prevalence of enteroviral capsid protein vp1 immunostaining in pancreatic islets in human type 1 diabetes. Diabetologia 2009;52:1143-51.

11. Tanaka S, Nishida $Y$, Aida $K$, et al. Enterovirus infection, CXC chemokine ligand 10 (CXCL10), and CXCR3 circuit: a mechanism of accelerated beta-cell failure in fulminant type 1 diabetes. Diabetes 2009;58:2285-91

12. Ylipaasto $\mathrm{P}$, Klingel $\mathrm{K}$, Lindberg $\mathrm{AM}$, et al. Enterovirus infection in human pancreatic islet cells, islet tropism in vivo and receptor involvement in cultured islet beta cells. Diabetologia 2004:47:225-39.

13. Shibasaki S, Imagawa A, Tauriainen S, et al. Expression of toll-like receptors in the pancreas of recent-onset fulminant type 1 diabetes. Endocr J 2010;57:211-19.

14. Yeung WC, Rawlinson WD, Craig ME. Enterovirus infection and type 1 diabetes mellitus: systematic review and meta-analysis of observational molecular studies. BMJ 2011;342:d35.

15. Frisk G, Grapengiesser E, Diderholm H. Impaired Ca2+ response to glucose in mouse beta-cells infected with coxsackie $B$ or Echo virus. Virus Res 1994;33:229-40.

16. Yin H, Berg AK, Westman J, et al. Complete nucleotide sequence of a Coxsackievirus B-4 strain capable of establishing persistent infection in human pancreatic islet cells: effects on insulin release, proinsulin synthesis, and cell morphology. J Med Virol 2002;68:544-57.

17. Weber F, Wagner V, Rasmussen SB, et al. Double-stranded RNA is produced by positive-strand RNA viruses and DNA viruses but not in detectable amounts by negative-strand RNA viruses. J Virol 2006;80:5059-64

18. Richardson SJ, Willcox A, Hilton DA, et al. Use of antisera directed against dsRNA to detect viral infections in formalin-fixed paraffin-embedded tissue. J Clin Virol 2010;49:180-5.

19. Gribaudo G, Lembo D, Cavallo G, et al. Interferon action: binding of viral RNA to the 40-kilodalton 2'-5'-oligoadenylate synthetase in interferon-treated HeLa cells infected with encephalomyocarditis virus. J Virol 1991;65:1748-57.

20. Tam PE, Messner RP. Molecular mechanisms of coxsackievirus persistence in chronic inflammatory myopathy: viral RNA persists through formation of a double-stranded complex without associated genomic mutations or evolution. J Virol 1999;73:10113-21.

21. Kim KS, Tracy S, Tapprich W, et al. 5'-Terminal deletions occur in coxsackievirus B3 during replication in murine hearts and cardiac myocyte cultures and correlate with encapsidation of negative-strand viral RNA. J Virol 2005;79:7024-41.

22. Heitmeier MR, Scarim AL, Corbett JA. Double-stranded RNA inhibits beta-cell function and induces islet damage by stimulating beta-cell production of nitric oxide. J Biol Chem 1999;274:12531-6.

23. Rhodes CJ, Taylor KW. Effect of interferon and double-stranded RNA on B-cell function in mouse islets of Langerhans. Biochem $J$ 1985;228:87-94.

24. Dogusan Z, Garcia M, Flamez D, et al. Double-stranded RNA induces pancreatic beta-cell apoptosis by activation of the toll-like receptor 3 and interferon regulatory factor 3 pathways. Diabetes 2008;57:1236-45.

25. Colli ML, Nogueira TC, Allagnat F, et al. Exposure to the viral by-product dsRNA or Coxsackievirus B5 triggers pancreatic beta cell apoptosis via a Bim / Mcl-1 imbalance. PLoS Pathog 2011;7:e1002267.

26. Scarim AL, Arnush M, Blair LA, et al. Mechanisms of beta-cell death in response to double-stranded (ds) RNA and interferon-gamma: dsRNA-dependent protein kinase apoptosis and nitric oxide-dependent necrosis. Am J Pathol 2001;159:273-83.

27. Skog O, Korsgren O, Frisk G. Modulation of innate immunity in human pancreatic islets infected with enterovirus in vitro. J Med Virol 2011;83:658-64.

28. Goto M, Eich TM, Felldin M, et al. Refinement of the automated method for human islet isolation and presentation of a closed system for in vitro islet culture. Transplantation 2004;78:1367-75

29. Frisk $\mathrm{G}$, Diderholm $\mathrm{H}$. Tissue culture of isolated human pancreatic islets infected with different strains of coxsackievirus B4: assessment of virus replication and effects on islet morphology and insulin release. Int J Exp Diabetes Res 2000;1:165-75.

30. Frisk G, Elfstrom T, Diderholm H. The replication of certain Coxsackie $\mathrm{B}$ virus strains in $\mathrm{CHO}$ cells. J Virol Methods 2001;98:161-5

31. Frisk G, Tuvemo T. Enterovirus infections with beta-cell tropic strains are frequent in siblings of children diagnosed with type 1 diabetes children and in association with elevated levels of GAD65 antibodies. J Med Virol 2004;73:450-9.

32. Elshebani A, Olsson A, Westman J, et al. Effects on isolated human pancreatic islet cells after infection with strains of enterovirus isolated at clinical presentation of type 1 diabetes. Virus Res 2007;124:193-203.

33. Kang Y, Chatterjee NK, Nodwell MJ, et al. Complete nucleotide sequence of a strain of coxsackie B4 virus of human origin that induces diabetes in mice and its comparison with nondiabetogenic coxsackie B4 JBV strain. J Med Virol 1994;44:353-61.

34. Moell A, Skog O, Ahlin E, et al. Antiviral effect of nicotinamide on enterovirus-infected human islets in vitro: effect on virus replication and chemokine secretion. J Med Virol 2009;81:1082-7.

35. Ravelli RB, Kalicharan RD, Avramut MC, et al. Destruction of tissue, cells and organelles in type 1 diabetic rats presented at macromolecular resolution. Sci Rep 2013;3:1804.

36. Cnop M, Hughes SJ, Igoillo-Esteve M, et al. The long lifespan and low turnover of human islet beta cells estimated by mathematical modelling of lipofuscin accumulation. Diabetologia 2010;53:321-30.

37. Fava E, Dehghany J, Ouwendijk J, et al. Novel standards in the measurement of rat insulin granules combining electron microscopy, high-content image analysis and in silico modelling. Diabetologia 2012;55:1013-23.

38. Dai C, Brissova M, Hang $Y$, et al. Islet-enriched gene expression and glucose-induced insulin secretion in human and mouse islets. Diabetologia 2012;55:707-18.

39. Innytska O, Santiana M, Hsu NY, et al. Enteroviruses harness the cellular endocytic machinery to remodel the host cell cholesterol 
landscape for effective viral replication. Cell Host Microbe 2013;14:281-93.

40. Bogan JS, Xu Y, Hao M. Cholesterol accumulation increases insulin granule size and impairs membrane trafficking. Traffic 2012;13:1466-80.

41. de Jong AS, Wessels E, Dijkman HB, et al. Determinants for membrane association and permeabilization of the coxsackievirus $2 \mathrm{~B}$ protein and the identification of the Golgi complex as the target organelle. J Biol Chem 2003;278:1012-21.

42. Sandoval IV, Carrasco L. Poliovirus infection and expression of the poliovirus protein $2 \mathrm{~B}$ provoke the disassembly of the Golgi complex, the organelle target for the antipoliovirus drug Ro-090179. J Virol 1997;71:4679-93.

43. van Kuppeveld FJ, Hoenderop JG, Smeets RL, et al. Coxsackievirus protein $2 \mathrm{~B}$ modifies endoplasmic reticulum membrane and plasma membrane permeability and facilitates virus release. EMBO $J$ 1997;16:3519-32.

44. Barco A, Carrasco L. A human virus protein, poliovirus protein 2BC, induces membrane proliferation and blocks the exocytic pathway in the yeast Saccharomyces cerevisiae. EMBO J 1995;14:3349-64.
45. Doedens JR, Kirkegaard K. Inhibition of cellular protein secretion by poliovirus proteins 2B and 3A. EMBO J 1995;14:894-907.

46. Lamphear BJ, Yan R, Yang F, et al. Mapping the cleavage site in protein synthesis initiation factor elF-4 gamma of the $2 \mathrm{~A}$ proteases from human Coxsackievirus and rhinovirus. $J$ Biol Chem 1993;268:19200-3.

47. Fred RG, Sandberg M, Pelletier $\mathrm{J}$, et al. The human insulin mRNA is partly translated via a cap- and elF4A-independent mechanism. Biochem Biophys Res Commun 2011;412:693-8.

48. Lindskog $\mathrm{C}$, Korsgren $\mathrm{O}$, Ponten $\mathrm{F}$, et al. Novel pancreatic beta cell-specific proteins: antibody-based proteomics for identification of new biomarker candidates. J Proteomics 2012;75:2611-20.

49. Gozuacik D, Bialik S, Raveh T, et al. DAP-kinase is a mediator of endoplasmic reticulum stress-induced caspase activation and autophagic cell death. Cell Death Differ 2008;15:1875-86.

50. Narayanan S, Stewart GC, Chengappa MM, et al. Fusobacterium necrophorum leukotoxin induces activation and apoptosis of bovine leukocytes. Infect Immun 2002;70:4609-20.

51. Taylor MP, Kirkegaard K. Modification of cellular autophagy protein LC3 by poliovirus. J Virol 2007;81:12543-53. 